\title{
Knowledge, attitudes, and practices of Sudanese residents towards COVID-19
}

Ahmed Hezima, ${ }^{1}$ Abdulmalek Aljafari, ${ }^{1}$ Abdulmoiz Aljafari, ${ }^{1}$ Abdulkader Mohammad ${ }^{1}$ and Ibrahim Adel $^{1}$

${ }^{1}$ Alneelain University, Khartoum, Sudan (Correspondence to: Abdulmalek Aljafari: abdulmalekaljafari@gmail.com).

\begin{abstract}
Background: Coronavirus disease 2019 (COVID-19) is a severe acute respiratory infection caused by severe acute respiratory syndrome coronavirus 2 (SARS-CoV-2). Sufficient knowledge, positive attitudes, and correct practices are crucial for the prevention of COVID-19.
\end{abstract}

Aims: This study aimed at assessing the knowledge, attitudes and practices of a sample of Sudanese residents towards COVID-19.

Methods: A cross-sectional community-based survey was conducted on 812 participants, including both sexes and aged 18 years and above, with the exclusion of health care workers. Considerable care was taken to include people with different education levels.

Results: Among the survey respondents ( $n=812$ ), $45.8 \%$ were women, $40.4 \%$ held a bachelor's degree, $5.7 \%$ were uneducated, and $51.1 \%$ were aged $18-25$ years. The overall correct rate of the knowledge questionnaire was $78.2 \% ; 66.9 \%$ agreed that religious gatherings and events should be cancelled to prevent the spread of COVID-19;34.1\% of respondents wore medical masks; and $57.9 \%$ avoided shaking hands in recent days.

Conclusion: This study showed that sampled Sudanese residents have incomplete knowledge and poor practices towards COVID-19. However, we found that women and people aged 18-25 years were more knowledgeable and had more positive attitudes towards COVID-19. We hope that concerned authorities will establish awareness programmes to improve the ability to combat this disease.

Citation: Hezima A; Aljafari A; Aljafari A; Mohammad A; Ibrahim Adel. Knowledge, attitudes, and practices of Sudanese residents towards COVID-19. East Mediterr Health J. 2020;26(6):646-651. https://doi.org/10.26719/emhj.20.076

Received: 05/04/20; accepted: 21/05/20

Copyright @ C World Health Organization (WHO) 2020. Open Access. Some rights reserved. This work is available under the CC BY-NC-SA 3.0 IGO license (https://creativecommons.org/licenses/by-nc-sa/3.o/igo)

\section{Introduction}

Coronavirus disease 2019 (COVID-19) is a potentially severe acute respiratory infection caused by severe acute respiratory syndrome coronavirus 2 (SARS-CoV-2). This novel coronavirus was firstly identified as the cause of an outbreak of pneumonia of unknown cause in Wuhan City, Hubei Province, China, in December 2019 (1). According to the World Health Organization (WHO), novel Coronavirus has been recorded in 202 countries. In response to this serious situation, WHO declared a public health emergency of international concern on 30 January 2020 and formally declaring it a pandemic on 11 March 2020 (2). Globally, 754948 cases have been reported as of 31 March 2020 (3). In Sudan, the Ministry of Health confirmed 7 cases from different age groups, 2 of which were fatal. There were also more than 99 suspected cases that are in isolation centres. The first case was announced on 13 March 2020. All confirmed cases are male travelers coming from outside Sudan. These cases arrived from different countries prior to the closure of Khartoum airport on 16 March 2020. Both deaths were patients aged over 55 years old. No cases of infection have been recorded in children (4).

The clinical presentation of the confirmed and suspected cases presented with symptoms of respiratory infection with symptom severity ranging from a mild common cold-like illness, to a severe viral pneumonia leading to acute respiratory distress syndrome that is potentially fatal. Symptoms included fever, cough, and shortness of breath. Other symptoms, such as malaise and respiratory distress, have also been described. In addition, some of those who tested positive for COVID-19 were asymptomatic, whereby symptoms may develop from 2 days to 2 weeks following exposure to the virus $(5,6)$.

Transmission of COVID-19 is believed to occur via respiratory droplets from coughing and sneezing, as with other respiratory pathogens, including influenza and rhinovirus. WHO officials project that the outbreak is containable if that pattern holds. No vaccine is currently available for SARS-CoV-2. Avoidance is the principal method of deterrence. General measures for prevention of viral respiratory infections include washing hands with water, use of a hand sanitizer, and avoiding touching the mouth, nose and eyes, especially if hands are unwashed. Also, avoidance of close contact with infected people, isolation for those who are infected, coughing and sneezing on a disposable tissue, and regular cleaning and disinfecting of surfaces that could be frequently touched is important for disease prevention (7).

This research was conducted in March 2020, a period where COVID-19 was new to Sudan and the situation was unclear. This could have affected the level of knowledge, 
attitudes, and practices of the Sudanese population towards the virus. Strong social bonds in the Sudanese community encourage frequent visits between families and neighbours, and the importance of handshaking in the culture may affect the practices of participants in this study. However, the effective infection prevention and control practices demands awareness and compliance among the populations at all levels. A poor level of knowledge has been implicated in the rapid spread of infection in societies, and vice versa. Therefore, the aim of this study was to assess the knowledge, attitudes and practices of Sudanese residents towards COVID-19 in March 2020.

\section{Methods}

\section{Study setting}

This study was conducted in Khartoum, Sudan, which has an estimated overall population of 5 million people (2008 census) (8). Although the questionnaire was distributed to local residents, residents of other states were also eligible to participate in the online questionnaire. Due to recent policies that restricted transportation between Sudanese states, the manual distribution of the questionnaire was eventually confined to Khartoum.

\section{Study design and population}

This was a cross-sectional, descriptive, community-based study conducted to gather information related to the knowledge, attitude, and practices towards COVID-19 among Sudanese residents in March 2020. A total of 812 participants completed the survey questionnaire. Sudanese nationals of both sexes and aged 18 years or above and who had agreed to participate were included and considered appropriate for the study; health care workers were excluded. Considerable care was taken to include people with different educational levels (i.e., no formal education, high school or below, undergraduate students, Bachelor's degree, Master's degree and above) by distributing both manual and online questionnaires to cover a wider segment of society.

Participants for this study were self-recruited via social media networking sites (an online soft copy using Google Forms to complete the questionnaire was made available through the popular social networking sites Facebook, Twitter, Whatsapp and Telegram). In addition, convenience sampling technique was used via manual distribution. However, It was not feasible to conduct a community-based survey throughout Sudan due to the policies that restricted movement between Sudanese states during this period. Therefore, distribution of the questionnaire was divided between manual distribution, which covered Khartoum, and online, which did not restrict participation from other states. Manual distribution of the questionnaire was also used to include sectors of the community who might not have access to social media.

Researchers were distributed across different areas in Khartoum, including residential areas, main roads, and local markets to include individuals from different sectors and backgrounds. Participants were randomly selected. An interview was conducted and the questionnaires were filled by the researchers after reading every question to each individual participant. Handling the questionnaires with participants was avoided as a protective measure. Researchers were committed to preventive measures, such as wearing medical masks and disposable gloves.

The total number of respondents was 812 after excluding those who refused to take part in the study. The sample size was calculated for cases from the equation $\mathrm{n}=\mathrm{z} 2 \mathrm{pq} / \mathrm{d} 2$, where $\mathrm{n}=$ sample size, $\mathrm{z}=$ level of confidence $=$ 1.96 (95\% CI), $P$ = prevalence. Since similar studies in Sudan on this topic are lacking, we assumed 50\% prevalence of having inadequate knowledge, attitudes, and practice. Therefore, $P=0.5, q=1-p=0.5, d=$ desired margin of error $=0.05$. Thus, the required sample size was estimated as (1.96) (1.96) (0.5) (0.5)/ (0.05)2 = 384 participants.

The online questionnaire was available from 5 to 26 March 2020 and the manual distribution was conducted during the same period. The responses to online questionnaires began to exceed manual responses when the sample size reached 384, therefore the number of manual participants was increased by researchers to compensate. On $26 \mathrm{March}$, when the total sample reached 812 , the online survey portal and manual distribution were closed.

\section{Data collection}

Following informed consent, data were collected via a 23-item structured, Arabic language, close ended and self-administered questionnaire online, while a hardcopy of the questionnaire was used by researchers to record answers from respondents who were physically present. The questionnaire was self-invented and underwent pilot survey. The questionnaire consisted of two parts: demographics and KAP, in addition to the consent question. Demographic variables included age, sex, and education level. The questionnaire had 23 questions: 4 regarding clinical presentations $\left(\mathrm{K}_{1}-\mathrm{K}_{3}\right.$ and $\left.\mathrm{K} 9\right)$ and 5 regarding transmission routes, prevention, and control (K4-K8) of COVID-19 (Table 1). These questions were answered on an agree/disagree basis with an additional "I don't know" option. A correct answer was assigned 1 point and an incorrect/unknown answer was assigned o points. The total knowledge score ranged from o to 9, with a higher score denoting a better knowledge towards COVID-19.

Attitudes towards COVID-19 were measured by 6 questions (A1-A6) about the country lockdown approval and the cancellation of religious gatherings, as well as the shutdown of schools, universities, and closing the borders of the country (Table 3). The assessment of respondents' practices was composed of 4 behaviours ( $\mathrm{P}_{1}-\mathrm{P}_{4}$, Table 4): avoiding going to a crowded place, wearing a medical mask, avoiding handshaking, and recently washing hands.

\section{Statistical analysis}

The analysis of data was done using SPSS, version 27.0. To calculate the frequencies of correct knowledge answers and various attitudes and practices, descriptive 


\begin{tabular}{lc}
\hline Table 1 Knowledge of Sudanese residents towards COVID-19 & Correct rate, \% of the \\
Question & 88.1 \\
K1. The main clinical symptoms of COVID-19 are fever, dry cough, and body aches? & 67.1 \\
K2. Unlike the common cold, sneezing and runny nose are less common in persons infected with the SARS-CoV-2 virus? & 15.8 \\
K3. All infected individuals are symptomatic? & 62.3 \\
K4. The disease can be transmitted from asymptomatic individuals? & 95.5 \\
K5. Avoiding crowded places can prevent the infection by SARS-CoV-2? & 95.1 \\
K6. Wearing medical masks and washing hands can prevent the infection by SARS-CoV-2? & 87.9 \\
K7. SARS-CoV-2 can be transmitted through respiratory droplets? & 94.9 \\
K8. Touching contaminated surfaces can facilitate the transmission of SARS-CoV-2? & 96.7 \\
K9. Elderly and those who have chronic illnesses are more likely to be severe cases? & \begin{tabular}{l} 
te \\
\hline
\end{tabular}
\end{tabular}

statistics were used. Independent samples, t test and oneway analysis of variance (ANOVA) were used to compare knowledge score, attitudes and practices of different participants according to demographic characteristics. For each attitude question, the percentage of respondents with positive responses was calculated. The statistical significance level was set at $P<0.05$.

\section{Results}

A total of 812 individuals participated in this study of whom $440(54.2 \%)$ were male and $372(45.8 \%)$ were female. Nearly half of the participants $(51.1 \%)$ were aged 18-25 years. The majority of participants (40.4\%) were Bachelor degree holders and only $5.7 \%$ had no formal education. Among the total number of participants, 544 (67\%) were recruited through online distribution and 268 (33\%) were recruited manually.

Responses to COVID-19 knowledge questions showed that out of the 9 questions, the mean score was 7.03 (SD: 1.3, range: $0-9)$, suggesting an overall $78.2 \%\left(7.03 / 9^{*} 100\right)$ correct rate on this knowledge test. The correct answer rates of the 9 questions on the COVID-19 knowledge questionnaire were $15.8-96.7 \%$ (Table 1). There were significant differences in knowledge scores across demographics (Table 2). Female participants were found to be more knowledgeable than male participants $(P=0.001)$. Participants aged 18-25 years were more knowledgeable than those in other age groups (26-35 years, $36-45$ years, 46-55 years, and $>55$ years, $P<0.05$ ) participants with no formal education were the least knowledgeable, with a mean score of 6.1 and an overall correct rate of $67.7 \%\left(6.1 / 99^{*} 100\right)$.

The vast majority of participants (93.4\%) believe that COVID-19 is a serious threat to public health. Rates of reporting "disagree" and "neutral" were 3.1\% and 3.4\%, respectively. Respondents reporting "disagree" and "neutral" had significantly lower knowledge scores than those reporting "agree" $(P<0.001)$. Nearly all participants (96.7\%) agreed that suspected and infected patients should be isolated and restricted from social contact. About two-thirds of participants $(66.9 \%)$ agreed that religious gatherings and events should be cancelled to help control the outbreak of COVID-19 (Table 3). The attitude towards

\begin{tabular}{lcc}
\hline $\begin{array}{l}\text { Table } 2 \text { Demographic characteristics of participants and knowledge score of COVID-19 by demographic variables } \\
\text { Education }\end{array}$ & $\begin{array}{c}\text { Number of participants } \\
(\%)\end{array}$ & $\begin{array}{c}\text { Knowledge score mean } \\
( \pm \text { standard deviation) }\end{array}$ \\
\hline Sex & & \multicolumn{1}{c}{$\boldsymbol{P}$} \\
$\quad$ Male & $440(54.2)$ & $6.9( \pm 1.3)$ \\
Female & $372(45.8)$ & $7.2( \pm 1.1)$ \\
Age-group (years) & & $7.2( \pm 0.9)$ \\
$18-25$ & $415(51.1)$ & $6.6( \pm 1.5)$ \\
$26-35$ & $179(22.0)$ & $6.8( \pm 1.6)$ \\
$36-45$ & $94(11.6)$ & $6.7( \pm 1.4)$ \\
$46-55$ & $87(10.7)$ & $6.9( \pm 1.4)$ \\
$>55$ & $37(4.6)$ & 6.001 \\
Education & & $6.1( \pm 2.0)$ \\
No formal education & $46(5.7)$ & $7.1( \pm 1.1)$ \\
High school or below & $183(22.5)$ & $7.0( \pm 1.1)$ \\
Undergraduate student & $190(23.4)$ & $7.1( \pm 1.2)$ \\
Bachelor's degree & $328(40.4)$ & $6.8( \pm 1.4)$ \\
Master's degree and above & $65(8.0)$ & $<0.001$ \\
\hline
\end{tabular}




\begin{tabular}{|c|c|c|}
\hline Question & $\begin{array}{c}\text { No. of } \\
\text { positive } \\
\text { responses }\end{array}$ & $\%$ \\
\hline A1. Do you agree that COVID-19 is a serious threat to public health? & 759 & 93.4 \\
\hline A2. Do you agree that suspected and infected patients should be isolated and restricted from social contact? & 786 & 96.7 \\
\hline A3. Do you agree that religious gatherings and events should be cancelled temporarily to prevent the spread of SARS-CoV-2? & 544 & 66.9 \\
\hline A4. Do you agree that universities and schools should be closed temporarily to prevent the spread of SARS-CoV-2? & 766 & 94.3 \\
\hline A5. Do you agree that your country should close their borders with other countries that have an outbreak of COVID-19? & 781 & 96.1 \\
\hline A6. Do you agree with the country lockdown to combat COVID-19? & 714 & 87.9 \\
\hline
\end{tabular}

cancelling religious gatherings significantly differed across genders, age-groups, and knowledge scores. Female (vs. male, $P<0.001$ ), participants aged 18-25 (vs. 46-55, $P=0.005)$, and higher knowledge score $(P<$ 0.001 ) had a more positive attitude towards cancelling religious gatherings and events. In addition, positive attitudes towards country lockdown, closing schools and universities, and closing borders with other countries that have an outbreak of COVID-19 showed significant association with higher knowledge score $(P<0.001)$.

Responses to practice questions showed that $34.1 \%$ of respondents wore masks, 57.9\% avoided shaking hands, $65.4 \%$ had not visited crowded places and $86.0 \%$ had been frequently washing their hands recently (Table 4). The rates of practices significantly differed across gender and age groups. Female (vs. male) was significantly associated with wearing masks $(P<0.001)$, avoiding crowded places $(P<0.001)$, and avoiding handshaking $(P<0.001)$. Participants aged over 55 years (vs. other age groups) were significantly associated with washing hands $(\mathrm{P}<0.001)$ and avoiding handshaking $(P \leq 0$.003). Moreover, higher knowledge scores were significantly associated with washing hands $(P=0.001)$ and avoiding handshaking $(P=0.005)$. Washing hands $(P=0.015)$ and avoiding crowded places $(P<0.001)$ were significantly associated with more positive attitude towards perception of COVID-19 as a serious threat.

The results from online distribution compared to the manually distributed questionnaire did not differ significantly in some parts of the questionnaire. A noticeable difference was in the number of participants with no formal education in the manual questionnaire (12.8\%) compared to the online questionnaire (2.4\%). A significant difference was noticed in the knowledge correct rate where online respondents had a correct rate of $81.2 \%$ and manual respondents had $71.5 \%$. The attitudes towards cancelling religious gatherings differed significantly among online compared to manual respondents. $73.7 \%$ of online respondents and only half (52.7\%) of manual respondents agreed that it should be cancelled. In the practices section of the questionnaire, less than half $(48.8 \%)$ of manual respondents and $61.9 \%$ of online respondents avoided handshaking.

\section{Discussion}

Awareness is a very important parameter to be assessed to provide baseline data to assist decision-makers to plan and deliver effective measures to prevent the spread of COVID-19. This study revealed some important aspects of COVID-19 awareness among the Sudanese residents. To the best of our knowledge, this is the first study in examining the KAP towards COVID-19 among the Sudanese residents. Our Participants were predominantly males and had intermediate educational levels. The overall correct rate was $78.2 \%$ in the Knowledge part of the questionnaire. This result is not satisfactory and does not reflect a high level of awareness. The disease did not yet reach the stage of outbreak in Sudan. As a result, there might be a matter of disregard in some segments of the society towards the disease.

Respondents in the manual questionnaire had a lower knowledge score than online respondents and they were also less educated. Education may have a direct effect on improving the knowledge, attitudes, and practices of the society, as educated people are more likely to be aware of the danger of the disease. Educated individuals may also be more likely to participate in the online questionnaire, as some of the respondents to the manual questionnaire could have been illiterate.

There were significant differences in knowledge scores across demographics. Gender showed an effect on awareness towards COVID-19, where female participants were found to be more knowledgeable than

\begin{tabular}{|c|c|c|}
\hline Question & $\begin{array}{c}\text { Yes } \\
\text { n(\%) }\end{array}$ & $\begin{array}{c}\text { No } \\
\mathrm{n}(\%)\end{array}$ \\
\hline P1. Have you been wearing medical masks when leaving your house in recent days? & $277(34.1)$ & $535(65.9)$ \\
\hline P2. Have you been frequently washing your hands in recent days? & $698(86.0)$ & $114(14.0)$ \\
\hline P3. Did you go to any crowded place in recent days? & $281(34.6)$ & $531(65.4)$ \\
\hline P4. Have you been avoiding handshaking with others in recent days? & 470(57.9) & $342(42.1)$ \\
\hline
\end{tabular}


male participants. This can be related to their innate fear for their children and family, which drives them to read and learn more about the disease. Age and level of education significantly affected the level of awareness towards COVID-19. Participants aged 18-25 years were more knowledgeable than those in other age groups. One reason for this may be related to their greater interest and access to social media, which played a major role in spreading awareness about COVID-19. Participants with no formal education were the least knowledgeable among educational levels, with a mean score of 6.1 and an overall correct rate of $67.7 \%\left(6.1 / 9^{*} 100\right)$. This may be due to their preoccupation with their livelihoods and that they are less likely to have access social media.

Despite the relatively low knowledge towards COVID-19, the vast majority of participants (93.4\%) believe that it is a serious threat to public health. This can be explained by the very high number of cases and deaths that increase every day around the world. About two-thirds of participants (66.9\%) agreed that religious gatherings and events should be cancelled, a percentage that is unsatisfactory, considering the role of gatherings in spreading the disease. The reason for this could be people's beliefs and emotional attachment to the places of worship. Only $34.1 \%$ of respondents wore masks. This may not be literally a lack of awareness as it is due to the inability of society to pay for it, and above all being in a country with poor economic status. While $57.9 \%$ avoided shaking hands, the rest are still handshaking, as avoiding handshaking is unacceptable in the Sudanese culture. $65.4 \%$ of participants had not visited crowded places and $86 \%$ have been frequently washing their hands recently. The poor practices, in general, among Sudanese residents can also be related to the many myths in Sudan, such as local herbs and hot climates being protective against the disease. Therefore, people do not follow the instructions on this regard as serious as they should. A similar study using an online survey was conducted in April 2020 in three Middle Eastern countries (Jordan, Saudi Arabia and Kuwait), showed an overall COVID-19 knowledge with a mean score of $66.1 \%, 15.3 \%$ of the participants did not go to crowded places, and 50.1\% wore a mask while leaving home (9). Another study conducted in Egypt in April 2020, showed a mean knowledge score of 16.39 out of $23(71.2 \%)(10)$.

Apparently, the Sudanese population seems to have a higher level of knowledge than other nearby Arab countries. Participants from Jordan, Saudi Arabia, and Kuwait wore a mask more frequently than Sudanese residents did. This might be attributed to the economic state of Sudan and the inability of the government to provide enough protective medical equipment to their residents.

\section{Limitations}

This study was limited by the fact that data were only taken from the capital city, Khartoum. Access to the rural and peripheral areas of Sudan could have improved the accuracy of the study.

\section{Conclusion and recommendations}

In summary, this research showed that the Sudanese residents still have incomplete knowledge about COVID-19, which could lead to an outbreak that is very difficult to control. Our findings suggest that women and people aged 18-25 years have had better knowledge towards COVID-19 during this outbreak. On the other hand, participants with no formal education were the least knowledgeable among the population. The study noted an association between education and positive attitudes and appropriate practices towards COVID-19, suggesting that education is helpful in encouraging a positive attitude and maintaining safe practices. Hopefully, In the coming days, the concerned authorities will work to establish awareness programs and put a long-term plan to improve access to education, so that the government and society can combat this disease and such tragedies.

Funding: None.

Competing interests: None declared.

\section{Connaissances, attitudes et pratiques vis-à-vis de la COVID-19 dans la population soudanaise}

Résumé :

Contexte : La maladie à coronavirus 2019 (COVID-19) est une infection respiratoire aiguë sévère causée par le coronavirus 2 du syndrome respiratoire aigu sévère (SRAS-CoV-2). Des connaissances suffisantes, des attitudes positives et des pratiques correctes sont cruciales pour la prévention de la COVID-19.

Objectifs : La présente étude a évalué les connaissances, les attitudes et les pratiques concernant la COVID-19 dans la population soudanaise.

Méthodes : Des enquêtes transversales au niveau communautaire ont été menées auprès de 812 participants, hommes et femmes de 18 ans et plus, à l'exclusion des agents de santé. Un soin considérable a été apporté pour inclure des personnes ayant des niveaux d'éducation différents.

Résultats : Parmi les personnes ayant répondu à l'enquête ( $\mathrm{n}=812), 45,8$ \% étaient des femmes, $40,4 \%$ étaient titulaires d'une licence, 5,7\% n'étaient pas diplômés et 51,1 \% étaient âgées de 18 à 25 ans. Le taux correct global du questionnaire sur les connaissances était de $78,2 \% ; 66,9 \%$ ont convenu que les rassemblements et les événements religieux devraient être annulés pour empêcher la propagation de la COVID-19; $34,1 \%$ des répondants portaient des masques médicaux; et 57,9\% ont évité de se serrer la main les jours avant l'enquête. 
Conclusion : La présente étude a montré que les connaissances concernant la COVID-19 sont encore incomplètes dans la population soudanaise et que les pratiques à ce sujet sont mauvaises. Cependant, nous avons constaté que les femmes et les personnes âgées de 18 à 25 ans étaient mieux informées et avaient des attitudes plus positives vis-à-vis de la COVID-19. Nous espérons que les autorités concernées mettront en place des programmes de sensibilisation pour améliorer la capacité de lutte contre cette maladie.

$$
\begin{aligned}
& \text { معلومات واتجاهات وممارسات السكان السودانيين تجاه كوفيد-19 } \\
& \text { احمد حزيمه، عبدالملك الجعفري، عبد المعز الجعفري، عبد القادر محمد، إبراهيم عادل }
\end{aligned}
$$

$$
\begin{aligned}
& \text { الخلفية: إن مرض فيروس كورونا } 2019 \text { (كوفيد-19) عدوى تنفسية حادة وخيمة ناجمة عن فيروس كورونا المسبب للمتلازمة التنفسية الحادة } \\
& \text { الوخيمة } 2 \text { (فيروس كورونا سارس - } \\
& \text { وتُعَدُّ المعرفة الكافية، والمو اقف الإيجابية، و الملمارسات الصحيحة أمرًا هامًا في الوقاية من كوفيد-19 } \\
& \text { الأهداف: هدفت هذه الدر اسة الم تقييم معلومات ومو اقف وممارسات عينة من السكان السو دانيين تجاه كوفيد-19 }
\end{aligned}
$$

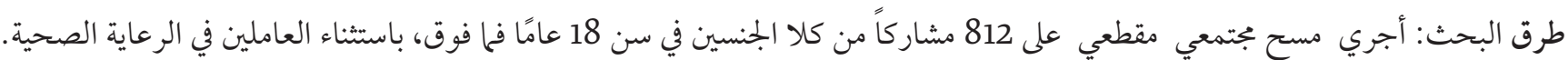

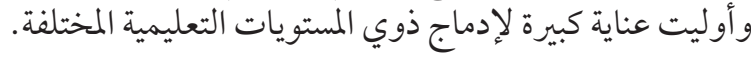

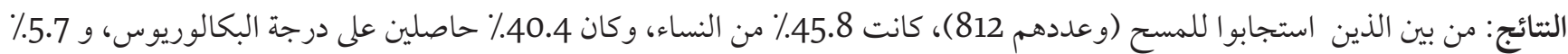

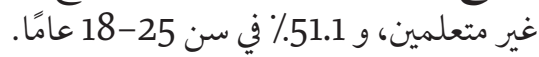

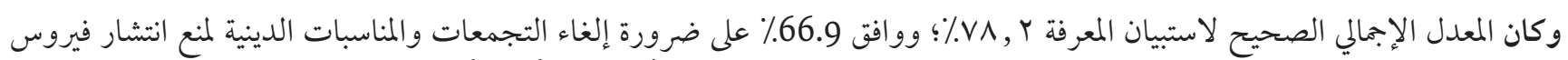

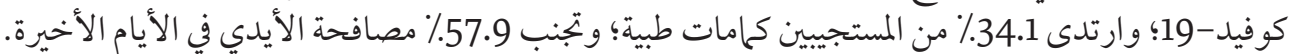

$$
\begin{aligned}
& \text { الاستنتاج: أظهرت الدر اسة أن العينة المختارة للسكان السودانيين ليس لديهم معرفة مكتملة وماز الت ممارساتهم سيئة تجاه كوفيد-19. }
\end{aligned}
$$

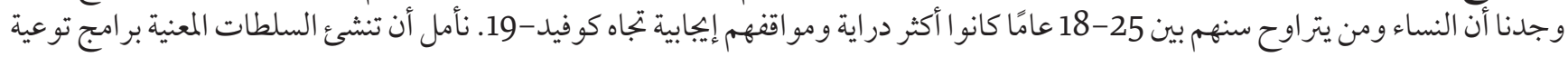

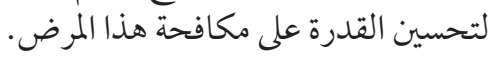

\section{References}

1. Ren L-L; Wang Y-M; Wu Z-Q; Xiang Z-C; Guo L; Xu T. Identification of a novel coronavirus causing severe pneumonia in human: a descriptive study. Chin Med J (Engl). 2020 May 5;133(9):1015-1024. doi: 10.1097/CM9.0000000000000722.

2. World Health Organization. Coronavirus (COVID-19) events as they happen. Geneva: World Health Organization; 2020 (https:// www.who.int/emergencies/diseases/novel-coronavirus-2019/events-as-they-happen).

3. Coronavirus disease (COVID-19) Situation Dashboard. (https://experience.arcgis.com/experience/685doace521648f8a5beeeee1b9125cd)

4. Federal Ministry of Health (https://www.fmoh.gov.sd).

5. Centers for Disease Control and Prevention (CDC). Symptoms of coronavirus disease 2019 (COVID-19) | Atlanta: CDC; 2020 (https://www.cdc.gov/coronavirus/2019-ncov/about/symptoms.html).

6. Hui DS, I Azhar E, Madani TA, Ntoumi F, Kock R, Dar O, et al. The continuing 2019-nCoV epidemic threat of novel coronaviruses to global health - The latest 2019 novel coronavirus outbreak in Wuhan, China. Vol. 91, Int J Infect Dis. 2020;91:264-6.

7. Cennimo DJ. Coronavirus disease 2019 (COVID-19) treatment \& management: approach considerations, medical care, prevention. Medscape online, 2020 (https://emedicine.medscape.com/article/2500114-treatment\#d8).

8. South Sudan Info Online. Wayback Machine (https://web.archive.org/web/20130520025735/http://southsudaninfo.net/wp-content/uploads/reference_library/reports/5th_sudan_census26_april_2009.pdf).

9. Naser AY, Dahmash EZ, Alwafi H, Alsairafi ZK3, Ahmed M; Rajeh A; Alhartani YJ. Knowledge and practices towards COVID-19 during its outbreak: a multinational cross-sectional study. medRxiv preprint doi.org/10.1101/2020.04.13.20063560. (https://www. researchgate.net/publication/340738054_Knowledge_and_practices_towards_COVID-19_during_its_outbreak_a_multinational_cross-sectional_study).

10. Abdelhafiz A, Mohammed Z, Ibrahim M, Ziady H, Alorabi M, Ayyad M, et al. Knowledge, Perceptions, and Attitude of Egyptians Towards the Novel Coronavi 